(C) The Author(s), 2020. Published by Cambridge University Press on behalf of The Nutrition Society. This is an Open Access article, distributed under the terms of the Creative Commons Attribution licence (http://creativecommons.org/licenses/by/4.0/), which permits unrestricted re-use, distribution, and reproduction in any medium, provided the original work is properly cited.

\title{
Can COVID-19 be a risk for cachexia for patients during intensive care? Narrative review and nutritional recommendations
}

\author{
Isabel P. A. Virgens ${ }^{1}$, Natália M. Santana ${ }^{1}$, Severina C. V. C. Lima ${ }^{2}$ and Ana P. T. Fayh ${ }^{1,2 *}$ \\ ${ }^{1}$ Graduate Program in Health Sciences, Federal University of Rio Grande do Norte, Natal, Rio Grande do Norte 59078-970, \\ Brazil \\ ${ }^{2}$ Graduate Program in Nutrition, Federal University of Rio Grande do Norte, Natal, Rio Grande do Norte 59078-970, Brazil \\ (Submitted 15 September 2020 - Final revision received 26 October 2020 - Accepted 26 October 2020 - First published online 5 November 2020 )
}

\section{Abstract}

Although increased weight, and particularly obesity, has been associated with a more severe clinical course of COVID-19 and risk of fatality, the course of the illness can lead to prolonged length of stay. Changes in nutritional status and weight loss during hospitalisation are largely reported in some populations, but still not explored in COVID-19 patients. Considering that patients with COVID-19 show an increased inflammatory response, other signs and symptoms, which can lead to weight and muscle loss, should be monitored. The aim of this article was to establish possible connections between COVID-19, prolonged hospitalisation and muscle wasting, as well as to propose nutritional recommendations for the prevention and treatment of cachexia, through a narrative review. Identification of risk and presence of malnutrition should be an early step in general assessment of all patients, with regard to more at-risk categories including older adults and individuals suffering from chronic and acute disease conditions, such as COVID-19. The deterioration of nutritional status, and consequently cachexia, increases the risk of mortality and needs to be treated with attention as other complications. There is, however, little hard evidence of nutritional approaches in assisting COVID-19 treatment or its management including cachexia.

Key words: Muscle wasting: Weight loss: Malnutrition: Coronavirus infections: Diet

In December 2019, an outbreak of pneumonia cases of unknown cause was reported by health facilities in Wuhan, Hubei province, China in which clusters of patients were associated with the seafood and wet animal wholesale market ${ }^{(1,2)}$. On 7 January 2020, the novel coronavirus which caused the illness was identified in a throat swab sample $e^{(2)}$. On 11 February 2020, the WHO stated a new name for the malady: coronavirus disease-2019 (COVID-19) ${ }^{(3)}$ and 1 month later declared it as a global pandemic ${ }^{(4)}$. As stated by the WHO, until 6 September 2020, nearly 27 million cases of COVID-19 were reported of which 900000 people died ${ }^{(5)}$.

COVID-19 is a respiratory disease caused by the novel coronavirus, severe acute respiratory syndrome coronavirus 2 (SARS$\mathrm{CoV}-2)$, that has reached pandemic status ${ }^{(6)}$. Underlying diseases and other risk factors might contribute to the severity of COVID19 patients. Chronic obstructive pulmonary disease, hypertension, diabetes, malnutrition, smoking habit, cerebrovascular disease, male sex, age over 65 years and obesity were reported to be associated with severe cases ${ }^{(7-14)}$. Although increased weight, and particularly obesity, has been associated with a more severe clinical course of COVID-19 and risk of fatality ${ }^{(15,16)}$, the course of the illness can lead to prolonged length of stay (LOS).
Changes in nutritional status and weight loss during hospitalisation are largely reported in some populations ${ }^{(17,18)}$, but still not explored in COVID-19 patients ${ }^{(19)}$. In fact, few studies reported nutritional status of patients during hospitalisation for COVID-19 ${ }^{(20)}$. Symptoms and associated conditions might contribute to nutritional status deterioration, leading to cachexia $^{(21)}$. Thus, the aim of this narrative review is to establish possible connections between COVID-19, prolonged hospitalisation and cachexia, and to propose nutritional recommendations for the prevention and treatment of such muscle wasting condition.

The literature review was conducted according to the SANRA Statement ${ }^{(22)}$ utilising PubMed, Lilacs, Google Scholar and Cochrane Library databases. First, to identify relevant publications about COVID-19 and cachexia, the combined search terms were used: (1) COVID-19 OR SARS-CoV-2, (2) cachexia OR muscle wasting and (3) diet OR nutrition. The inclusion criteria were studies published from January 2020 to 11 August 2020, published in English. Afterwards, to further discuss the relationship between COVID-19 infection, diet and loss of weight and muscle mass, relevant articles from the nutrition and cachexia area (including clinical characteristics and symptoms) were included.

Abbreviations: COVID-19, coronavirus disease-2019; CT, computed tomography; ICU, intensive care unit; LOS, length of stay; SARS-CoV-2, severe acute respiratory syndrome coronavirus 2 .

* Corresponding author: Ana P. T. Fayh, email apfayh@yahoo.com.br 


\section{How can COVID-19 induce weight loss?}

The virus SARS-CoV-2 is commonly transmitted through respiratory droplets, contact and potentially via the faecal-oral route $^{(23,24)}$. First, viral replication occurs in the upper respiratory tract and subsequently reaches the lower respiratory tract and other tissues and organs, including the gastrointestinal tract ${ }^{(24)}$. In addition to respiratory symptoms, gastrointestinal symptoms caused by SARS-CoV-2 were also reported and they appear to exacerbate malnutrition in patients ${ }^{(20)}$. Therefore, COVID-19 was reported to be associated with malnutrition in some studies ${ }^{(20,25,26)}$. Diarrhoea, mild abdominal pain, nausea, vomiting, poor appetite and other symptoms were commonly reported and can cause reduction in food intake and/or absorption, and consequently weight loss ${ }^{(27)}$.

Another possible important implication to weight loss is the acute inflammatory chain in response to the SARS-CoV-2 infection. The virus has spike (S) proteins, a glycoprotein that has high affinity with the angiotensin-converting enzyme 2 receptor, which is the mediator of virus entry ${ }^{(28,29)}$. Angiotensinconverting enzyme 2 in the gastrointestinal tract has been identified in several studies, but it is widely expressed in various organs considered target for SARS-CoV-2 in humans, such as the nasal mucosa, bronchus, lung, heart, oesophagus, kidney and bladder $^{(24,30)}$

Once the virus entry occurs, the rapid viral replication and a series of reactions begin such as cellular damage, the cytokine storm and antibody-dependent enhancement ${ }^{(24,30,31)}$. The process referred above as 'cytokine storm' is characterised as the presentation of the viral antigens to the natural killer and CD8-positive cytotoxic $\mathrm{T}$ cells in the context of major tissue histocompatibility $^{(31)}$.

After this event, it is possible that massive epithelial and endothelial cell death and vascular leakage happen, triggering the production of several pro-inflammatory cytokines and chemokines, which are responsible for the aggressive inflammation caused by SARS-CoV-2 ${ }^{(24,30)}$. In this regard, acute phase proteins such as C-reactive protein, ferritin, TNF $\alpha$, IL family factors, $\mathrm{NF}-\kappa \mathrm{B}$, interferon- $\gamma$, fibroblast growth factor and others are synthesised ${ }^{(20)}$. Antibody-dependent enhancement can promote interactions between virus-anti-S protein-neutralising antibodies and target cell receptors that can increase inflammatory response as well ${ }^{(24)}$.

All these processes are directly related to the increase of muscle proteolysis, albumin consumption and impaired metabolism of macronutrients which can contribute to the onset of malnutrition and cachexia ${ }^{(30)}$. A cross-sectional study evaluating malnutrition in 182 COVID-19 hospitalised elderly patients (mean age 68.5 (SD 8.8) years) in China found that subjects classified as malnourished showed significantly lower albumin levels and calf circumference ${ }^{(20)}$. However, changes in fat deposits and age-related loss of skin elasticity may contribute to errors in estimating muscle mass in the elderly ${ }^{(32)}$.

Considering that patients with COVID-19 show an increased inflammatory response upon hospital admission ${ }^{(14)}$, other signs and symptoms which can lead to weight and muscle loss should be monitored. Table 1 shows some studies in which symptoms may contribute to weight loss in COVID-19 patients. Notably, there is lack of information regarding some symptoms in these reports. It is also important to emphasise the lack of information regarding nutritional status, including BMI and weight loss in these studies. BMI was reported in a few studies in COVID-19 patients, although this marker of nutritional status has a significant association with the illness severity ${ }^{(15,39-41)}$. Older age and the presence of co-morbid conditions are almost invariably associated with impaired nutritional status and sarcopenia, independently of $\mathrm{BMI}^{(42)}$.

Based on available clinical observations, it is evident that although people of all ages can become infected and present weight loss, elderly people with low immunity and patients with chronic diseases have a worse prognosis and have a higher risk of cachexia. So, it is important to highlight the importance of weight loss monitoring and nutritional status vigilance for these patients. Nutritional therapy should be regarded as first-line treatment and implemented into standard of practice ${ }^{(25)}$, representing primary guarantee for promoting disease recovery.

\section{Interrelations between prolonged hospitalisation, weight loss and risk of cachexia}

SARS-CoV-2 manifestation and COVID-19 disease might be asymptomatic or present moderate to severe symptoms. In moderate and more severe cases, hospitalisation is necessary and complications can include acute respiratory distress syndrome, acute cardiac complications, multiple organ dysfunction syndrome, septic shock and death ${ }^{(43)}$. These complications have been described as the cytokine storm, in which viral replication triggers an abnormally strong release of cytokines and other immune-related stimuli, resulting in inflammation ${ }^{(14)}$ and weight loss ${ }^{(20)}$

Identification of risk and presence of malnutrition should be an early step in the general assessment of all patients, with regard to more at-risk categories including older adults and individuals suffering from chronic and acute disease conditions, as COVID-19. Malnutrition can be defined as any nutritional imbalance which can happen both in underweight and overweight individuals ${ }^{(44)}$. This imbalance can be originated from different conditions such as insufficient nutrient intake, higher energy requirements, impaired absorption and/or changes in nutrient utilisation and transport ${ }^{(45)}$. In addition, malnourished patients have higher risks of poorer outcomes such as longer length of hospital stay, muscle wasting, postoperative complications, depression of the immune system and mortality ${ }^{(44)}$.

It is well known that a healthy nutritional status is important for immune system support and to prevent severe infections ${ }^{(14)}$. Nevertheless, the nutritional status of people with viral infections was not described to be a risk factor in the emergence of viral diseases which could be due to a lack of data, making it even more important to be reported ${ }^{(29)}$. In COVID-19 patients, these challenges appear to result from the direct effects of the SARS$\mathrm{CoV}-2$ virus on the gastrointestinal tract and are compounded by the elevated sedation required for this patient ${ }^{(46)}$. Also, the elevated doses of sedatives and opioids required to facilitate mechanical ventilation in patients with COVID-19 can contribute to intestinal dysmotility and weight loss ${ }^{(25)}$ which may lead to 
Table 1. COVID-19 symptoms potentially related to weight loss and cachexia

(Mean values and standard deviations; medians and interquartile ranges (IQR))

\begin{tabular}{|c|c|c|c|c|c|c|c|c|}
\hline \multirow[b]{2}{*}{ Study } & \multirow[b]{2}{*}{ Country } & \multirow[b]{2}{*}{ Study design } & \multirow{2}{*}{$\begin{array}{l}\text { Number of } \\
\text { patients }\end{array}$} & \multicolumn{3}{|c|}{ Age (years) } & \multirow[b]{2}{*}{ Sex } & \multirow{2}{*}{$\begin{array}{l}\text { COVID-19 symptoms potentially related } \\
\text { to weight loss and cachexia }\end{array}$} \\
\hline & & & & Mean & & SD & & \\
\hline Chen et al.(2) & China & Retrospective cohort & 99 & $55 \cdot 5$ & & $13 \cdot 1$ & $\begin{array}{l}\text { Male }(68 \%) \\
\text { female }(32 \%)\end{array}$ & $\begin{array}{l}\text { Decreased } \mathrm{Hb} \\
\text { Decreased albumin } \\
\text { Increased C-reactive protein } \\
\text { Increased IL-6 } \\
\text { Fever } \\
\text { Muscle ache } \\
\text { Headache } \\
\text { Diarrhoea } \\
\text { Nausea and vomiting }\end{array}$ \\
\hline $\begin{array}{l}\text { Huang et al. } \\
\text { Median } \\
\text { IQR }\end{array}$ & China & Prospective cohort & 41 & & $\begin{array}{c}49 \\
41-58\end{array}$ & & $\begin{array}{l}\text { Male }(73 \%) \\
\text { female }(27 \%)\end{array}$ & $\begin{array}{l}\text { Decreased albumin } \\
\text { Fever } \\
\text { Myalgia or fatigue } \\
\text { Headache } \\
\text { Diarrhoea }\end{array}$ \\
\hline Li et al. ${ }^{(20)}$ & China & Cross-sectional & 182 & $68 \cdot 5$ & & $8 \cdot 8$ & $\begin{array}{c}\text { Female }(64 \%) \\
\text { male }(36 \%)\end{array}$ & $\begin{array}{l}\text { Decreased } \mathrm{Hb} \\
\text { Decreased albumin } \\
\text { Increased C-reactive protein }\end{array}$ \\
\hline Jin et al. ${ }^{(28)}$ & China & Retrospective cohort & 74 & $46 \cdot 14$ & & $14 \cdot 2$ & $\begin{array}{c}\text { Female }(50 \%) \\
\text { male }(50 \%)\end{array}$ & $\begin{array}{l}\text { Increased C-reactive protein } \\
\text { Fever } \\
\text { Fatigue } \\
\text { Muscle ache } \\
\text { Headache } \\
\text { Diarrhoea } \\
\text { Nausea and vomiting }\end{array}$ \\
\hline $\begin{array}{l}\text { Wan et al. } \\
\text { Median } \\
\text { IQR }\end{array}$ & China & Case series & 135 & & $\begin{array}{c}47 \\
36-55\end{array}$ & & $\begin{array}{l}\text { Male }(53 \%) \\
\text { female }(47 \%)\end{array}$ & $\begin{array}{l}\text { Decreased albumin } \\
\text { Increased C-reactive protein } \\
\text { Fever } \\
\text { Myalgia or fatigue } \\
\text { Loss of appetite } \\
\text { Diarrhoea }\end{array}$ \\
\hline $\begin{array}{l}\text { Brill et al. }{ }^{(35)} \\
\text { Median } \\
\text { IQR }\end{array}$ & UK & Retrospective cohort & 450 & & $\begin{array}{c}72 \\
56-83\end{array}$ & & $\begin{array}{l}\text { Male }(60 \%) \\
\text { female }(40 \%)\end{array}$ & Increased C-reactive protein \\
\hline Xiong et al. ${ }^{(37)}$ & China & Retrospective cohort & 42 & $49 \cdot 5$ & & $14 \cdot 1$ & $\begin{array}{l}\text { Male }(60 \%) \\
\text { female }(40 \%)\end{array}$ & $\begin{array}{l}\text { Increased C-reactive protein } \\
\text { Fever } \\
\text { Fatigue } \\
\text { Diarrhoea }\end{array}$ \\
\hline Li et al. ${ }^{(38)}$ & China & Retrospective cohort & 90 & $45 \cdot 5$ & & $12 \cdot 3$ & $\begin{array}{l}\text { Male }(53 \%) \\
\text { female }(47 \%)\end{array}$ & $\begin{array}{l}\text { Increased C-reactive protein } \\
\text { Fever } \\
\text { Myalgia } \\
\text { Headache } \\
\text { Abdominal pain/diarrhoea }\end{array}$ \\
\hline
\end{tabular}

cachexia. Fig. 1 illustrates, in a didactic way, how the frequent manifestations presented by patients with COVID-19 can induce weight loss and, consequently, cachexia.

Cachexia is a complex metabolic syndrome associated with underlying illness and characterised by loss of muscle with or without loss of fat mass ${ }^{(47)}$. Cachexia can also be defined as 'weight loss in the presence of illness, combined with three or more of the following five criteria: decreased handgrip strength, fatigue, anorexia, low fatty free mass index (FFMI) or abnormal biochemistry (high C-reactive protein, low hemoglobin or low albumin), (48). Many of these factors that must be associated with weight loss for the diagnosis of cachexia are frequent symptoms in COVID-19 patients. Table 2 shows the interrelations between the signs and symptoms present in cachexia syndrome and COVID-19 patients.

To date, data regarding decreased muscle strength and low fat-free mass index were not reported in recent studies in patients with COVID-19. However, they could be further explored using a hand dynamometer for assessing muscle strength and computed tomography (CT) acquired as part of standard COVID-19 to the determination of body composition and diagnosis of muscle mass reduction in these patients. The use of imaging diagnostics for body composition makes maximal use of existing information and could help to recognise 


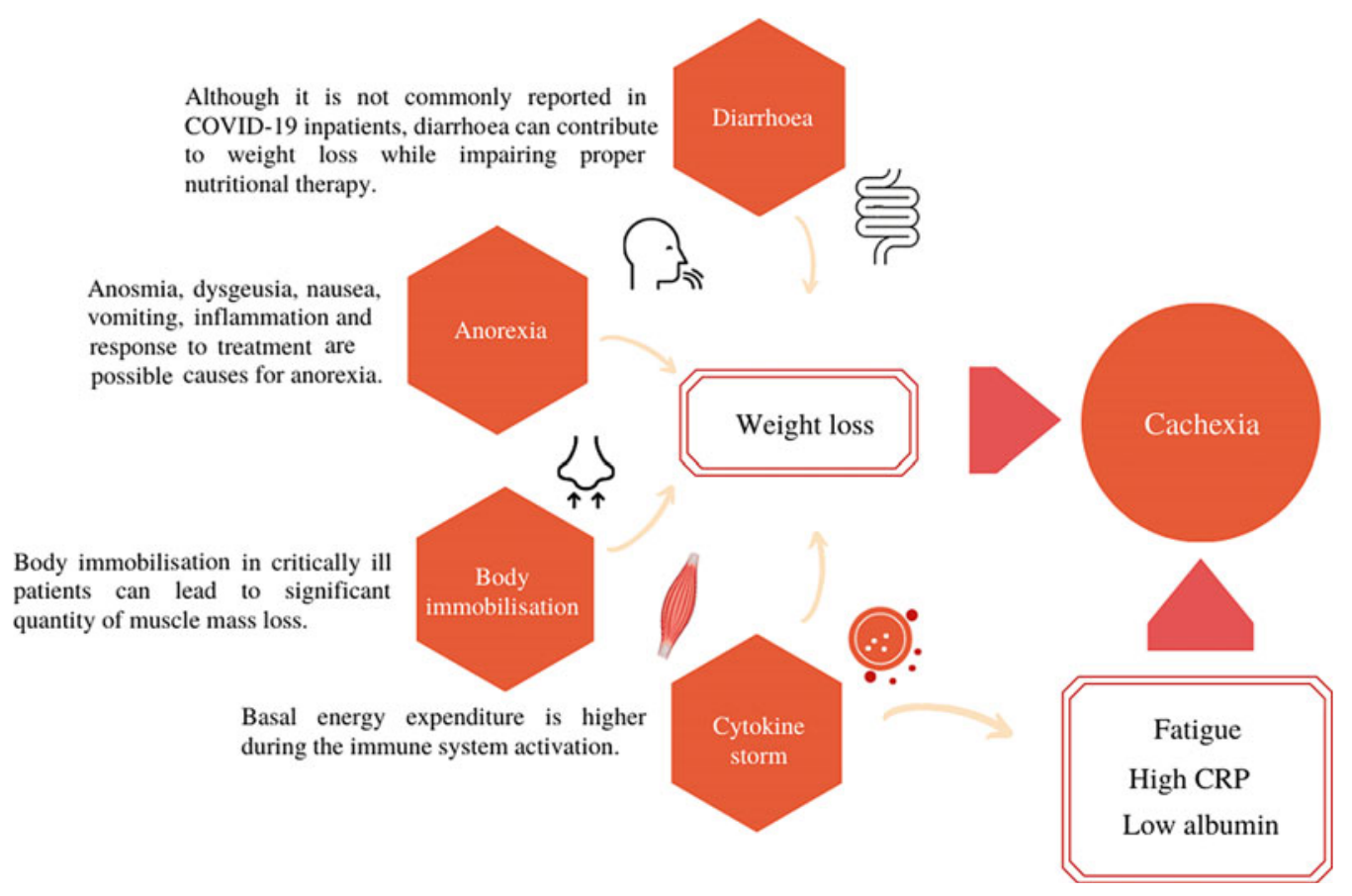

Fig. 1. Symptoms in COVID-19 inpatients related to the onset of cachexia. CRP, C-reactive protein.

Table 2. Interrelations between the signs and symptoms present in cachexia and COVID-19 patients

\begin{tabular}{|c|c|c|}
\hline \multicolumn{3}{|c|}{ Cachexia and its relation to COVID-19 } \\
\hline $\begin{array}{l}\text { Definition of } \\
\text { cachexia }^{(48)}\end{array}$ & $\begin{array}{c}\text { Weight loss of at least } \\
5 \% \text { in } 3 \text { months } \\
\left.\text { (or BMl }<20 \mathrm{~kg} / \mathrm{m}^{2}\right)+ \\
\text { (minimum three items) }\end{array}$ & $\begin{array}{l}\text { (1) Decreased muscle } \\
\text { strength } \\
\text { (2) Fatigue* } \\
\text { (3) Anorexia* } \\
\text { (4) Decreased fat-free mass } \\
\text { index } \\
\text { (5) Decreased biochemistry } \\
\text { levels (high C-reactive } \\
\text { protein*, low Hb, or low } \\
\text { albumin*) }\end{array}$ \\
\hline
\end{tabular}

* The signs and symptoms usually observed in COVID-19 patients.

and treat patients at increased risk of wasting with targeted pathways. In fact, some studies have already used CT images to describe the body composition of patients with COVID-19 ${ }^{(49-51)}$, showing that an inadequate body composition increases the risk of complications from the disease. In general, crosssectional analysis of single CT images, typically landmarked at the 3 rd lumbar vertebra (L3), is conducted ${ }^{(52,53)}$. It is possible that some CT images of patients with COVID-19 do not include the $\mathrm{L} 3$ region, but it is still possible to estimate body composition in other regions of the abdomen, as the thoracic area ${ }^{(54)}$. The information obtained through CT analysis, quantifying the patient's muscle mass, can improve the care of the critically ill patient, establishing early conducts for the cachexia management.

Fatigue is a debilitating symptom commonly reported by COVID-19 patients ${ }^{(55)}$. Its aetiology and pathophysiology are not well understood yet, still it is suggested that both central and peripheral mechanisms are involved in the physical expression of fatigue ${ }^{(56)}$. Up to date, the exact duration of this symptom is not reported by the studies as well, it is still unclear for how long patients can experience COVID-19-related fatigue. This could be due to the 'cytokine storm' leading to inflammation and anorexia, both responsible for muscle loss, weakness and fatigue. Also, infections contribute to higher basal energy expenditure during the immune system activation in which fever is a common symptom ${ }^{(57)}$. Still, studies regarding the aetiology of fatigue, its duration and associated diseases in COVID-19 patients have to be better explored.

Anorexia has also been reported as a common symptom in recent meta-analyses ${ }^{(58-60)}$. It is a complex and multifactorial symptom which can occur in the presence of acute inflammatory disease adverse reactions to treatment, depression, altered liver function and hypoxia ${ }^{(61,62)}$. Diarrhoea, nausea and vomiting were less frequent gastrointestinal symptoms than anorexia ${ }^{(60)}$. It is important to mention the presence of dysgeusia and anosmia of COVID-19 as possible contributors of anorexia.

There is expressive evidence of low albumin, other inflammation biomarkers, anorexia and fatigue as common symptoms in patients with COVID-19. Observational studies show low albumin in severe cases ${ }^{(34,63)}$. A meta-analysis has reported that severe cases of COVID-19 were associated with hypoalbuminaemia, but the relation between the disease and the biomarker is still unclear ${ }^{(63)}$. Albumin circulating levels should not be considered as a nutritional marker in patients with inflammatory response $^{(21,42)}$, but this biochemical marker has good relation with muscle mass and high-sensitive C-reactive protein.

High high-sensitive C-reactive protein usually observed in COVID-19 patients, confirming its viral aetiology as well as a biomarker of cachexia, is commonly altered in patients as a result of the 'cytokine storm' which increases the severity of COVID-19(34,55,64,65). The rapid recruitment of neutrophils and 
macrophages causes an exacerbated reaction to infections producing pro-inflammatory cytokines and modifying the fragile balance between the host-damaging reaction and a controlled immune response ${ }^{(66)}$. The acute phase protein is a sensitive biomarker in which the up-regulated synthesis occurs in tissue damage, malignant neoplasia, infections and inflammation ${ }^{(67)}$.

Low $\mathrm{Hb}$ is a biomarker present in the cachexia syndrome, and it was reported in COVID-19 patients in a few studies ${ }^{(2,20)}$. However, it may be worth evaluating the role of $\mathrm{Hb}$ in the pathophysiology of COVID-19 and investigating its relation to the illness and adverse outcomes. Sotoudeh et al. ${ }^{(68)}$ reported that the mortality rate of COVID-19 patients is lower in countries with a higher prevalence of haemoglobinopathies. This finding does not prove the direct association, and the observed finding can be due to other confounding variables or poor patient detection in tropical countries. A systematic review shows that six studies described low $\mathrm{Hb}$ in patients with COVID-19, while four studies found that all patients had $\mathrm{Hb}$ within the reference interval ${ }^{(69)}$. However, a limitation for this alteration is that most studies reported laboratory analysis from the patients at admission.

Few studies reported how the severity of COVID-19 leads to longer LOS compared with milder cases ${ }^{(70,71)}$. Bhatraju et al. showed that the median LOS among survivors of critically ill COVID-19 patients was $17 \mathrm{~d}$ (interquartile range, 16-23), and the median length of intensive care unit (ICU) stay among survivors was $14 \mathrm{~d}$ (interquartile range, 4-17). Prolonged length of hospital stay may be accompanied by loss in weight and muscle mass ${ }^{(72)}$, leading to cachexia $^{(73,74)}$. LOS is usually lacking information in COVID-19 reports, and it should be given more attention considering it is an adverse outcome. Thus, nutrition therapy in patients with cachexia can be effective, and it was shown to significantly reduce $\operatorname{LOS}^{(75)}$.

\section{Prevention and treatment of COVID-19 cachectic patients} through diet

Although most critically ill patients with COVID-19 are overweight or obese ${ }^{(15)}$, they are often sick at home for days to weeks prior to being admitted to the hospital, thus increasing their likelihood of being malnourished upon presentation ${ }^{(46)}$.

Malnutrition differs from cachexia due to its complex nature which combines an underlying disease, metabolic alterations and sometimes a reduced nutrient availability which might play an important role on the onset of the syndrome ${ }^{(21)}$, while malnutrition is not described as a syndrome but an altered state of nutrition due to different causes. Therefore, cachexia must be distinguished from other causes of muscle loss. The clinical consequences of cachexia depend as much on the weight loss as on the systemic inflammation, which accompany the development of cachexia ${ }^{(76)}$. Muscle, bone and fat tissue loss are also reported in cachexia ${ }^{(77,78)}$. Prolonged length of hospital stay is another situation that may be accompanied by loss in weight and muscle mass ${ }^{(72)}$. Although nutrition therapy is essential to promote better outcomes for patients, it is still often overlooked in clinical practice $^{(44)}$.

Established interventions to treat cachexia are available for specific underlying diseases, for example, progestogens ${ }^{(79)}$, corticosteroids and other different approaches including, for example, myostatin antagonists, ghrelin agonists, selective androgen receptor antagonists were described ${ }^{(80)}$. To impair muscle mass loss, exercises should be included in the treatment even in the individual with advanced cachexia to reduce muscle mass and physical function loss ${ }^{(81)}$

The European Society for Clinical Nutrition and Metabolism and other authors proposed general nutritional recommendations for all stages of COVID-19 $9^{(25,26,82)}$. However, there is no data in the literature regarding nutritional recommendations for the prevention and treatment of cachexia in COVID-19 patients. The European Society for Clinical Nutrition and Metabolism document aims to provide concise statements from experts and practical guidelines for the nutritional management of patients with COVID-19, whether for adults with polymorbidity or those in the ICU setting, which are independent factors associated with malnutrition and negative outcomes $^{(82)}$. In summary, this reference guides an energy supply between 27 and $30 \mathrm{kcal} / \mathrm{kg}$ per d (113 and $126 \mathrm{~kJ} / \mathrm{kg}$ per d) (according to the nutritional status), and a protein supply of $1 \mathrm{~g} / \mathrm{kg}$.

A recent review summarised the clinical Chinese observations and compared them with the references brought by European Society for Clinical Nutrition and Metabolism's guidelines ${ }^{(26)}$. Zhang \& Liu $^{(29)}$ proposed several treatment options (including nutritional interventions) for the novel coronavirus, based on a review of the current literature ${ }^{(41)}$. There are macronutrient recommendations for patients with COVID-19 pointed out in those studies. For lipid and carbohydrate needs, it is possible to consider an energy ratio from fat and carbohydrates from total estimated energy in a percentual distribution of 30:70 for subjects with no respiratory deficiency to 50:50 in ventilated patients ${ }^{(82)}$. It can also be considered $2 \mathrm{~g} / \mathrm{kg}$ per $\mathrm{d}$, not exceeding $150 \mathrm{~g} / \mathrm{d}$ for carbohydrate and $1.5 \mathrm{~g} / \mathrm{kg}$ per $\mathrm{d}$ for fat in critically ill patients ${ }^{(25)}$.

In COVID-19 intubated and ventilated ICU patients, enteral nutrition should be started. European Society for Clinical Nutrition and Metabolism suggests that in the early phase of the acute illness, a hypoenergetic nutrition of $20 \mathrm{kcal} / \mathrm{kg}$ per $\mathrm{d}$ $(84 \mathrm{~kJ} / \mathrm{kg}$ per d) should be administered (not exceeding $70 \%$ of estimated energy) with increments up to 80-100\% after the third day. During critical illness, $1.3 \mathrm{~g} / \mathrm{kg}$ protein equivalents per $\mathrm{d}$ can be delivered progressively. The use of enteral $n-3$ fatty acids may improve oxygenation despite strong evidence still not being available ${ }^{(82,83)}$. Up to date, the studies described in literature discuss nutritional management in ICU patients with cachexia due to other causes and report the importance of using specific nutrients, especially amino acids, to minimise excessive muscle mass loss ${ }^{(83)}$.

Leucine has been shown to be a potent stimulator of protein synthesis via the mammalian target of rapamycin complex pathway. It has recently been shown to be effective in elderly subjects with sarcopenia ${ }^{(84)}$. It may be extrapolated for COVID-19 patients with cachexia, but this use needs more studies. Arginine and glutamine are nonessential amino acids that are widely discussed in the literature for critically ill patients, but their role in muscular recovery is still unclear ${ }^{(83)}$. A recent report on nutritional support in patients with COVID-19 
Table 3. Prevention and treatment of malnutrition and cachexia in COVID-19 patients

\begin{tabular}{|c|c|c|}
\hline Energy & Protein & Other recommendations \\
\hline \multicolumn{3}{|l|}{ Pre-intubation and/or oral diet } \\
\hline $25-30 \mathrm{kcal} / \mathrm{kg}(105-126 \mathrm{~kJ} / \mathrm{kg})$ & $1.0 \mathrm{~g} / \mathrm{kg}$ & $\begin{array}{l}\text { It should be individually adjusted regarding nutritional status, physical activity } \\
\text { level, disease status and tolerance }\end{array}$ \\
\hline \multicolumn{3}{|l|}{ Intubation and/or enteral diet } \\
\hline $\begin{array}{l}21-30 \mathrm{kcal} / \mathrm{kg}(88-126 \mathrm{~kJ} / \mathrm{kg}) \\
\text { (eutrophic) }\end{array}$ & $1.2-2.5 \mathrm{~g} / \mathrm{kg}$ & $\begin{array}{l}\text { For patients with gastric residuals above } 500 \mathrm{ml} \text {, the ESPEN guidelines }{ }^{\left({ }^{2} 3\right)} \\
\text { recommend placement of a post-pyloric feeding tube as soon as possible }\end{array}$ \\
\hline \multicolumn{3}{|l|}{$\begin{array}{l}11-25 \mathrm{kcal} / \mathrm{kg}(46-105 \mathrm{~kJ} / \mathrm{kg}) \\
\text { (obese) }\end{array}$} \\
\hline $\begin{array}{l}<20 \mathrm{kcal} / \mathrm{kg}(<84 \mathrm{~kJ} / \mathrm{kg}) \text { (paren- } \\
\text { teral nutrition) }\end{array}$ & $1.3 \mathrm{~g} / \mathrm{kg}$ (parenteral nutrition) & \\
\hline \multicolumn{3}{|l|}{ Rehabilitation } \\
\hline $25-30 \mathrm{kcal} / \mathrm{kg}(105-126 \mathrm{~kJ} / \mathrm{kg})$ & $0.8-1.2 \mathrm{~g} / \mathrm{kg}$ & $\begin{array}{l}\text { Leucine: } 3 \% / \mathrm{d} \\
\text { L-Carnitine: } 2-4 \mathrm{~g} / \mathrm{d} \text { orally } \\
n-3 \text { (EPA): } 2 \mathrm{~g} / \mathrm{d} \\
\text { HMB: } 1 \cdot 5-3 \mathrm{~g} / \mathrm{d} \text { (along with exercise stimulation) }\end{array}$ \\
\hline
\end{tabular}

ESPEN, European Society for Clinical Nutrition and Metabolism; HMB, $\beta$-hydroxy- $\beta$-methylbutyrate.

reaffirmed the use of arginine for immunity and healing, as well as the role of glutamine in preserving intestinal function, but not in muscle recovery in either nutrient ${ }^{(25)}$.

$n$-3 PUFA, $\beta$-hydroxy- $\beta$-methylbutyrate (HMB) and $\mathrm{L}^{-}$ carnitine $^{(76,85,86)}$ are some other target nutrient suggestions for the recovery process. $n$ - 3 PUFA have shown to optimise tissue recovery ${ }^{(76)}$. A systematic review with $\mathrm{HMB}$ concluded that this amino acid metabolite attenuates exercise-induced muscle damage and enhances muscle hypertrophy and strength ${ }^{(86)}$. L-Carnitine supplementation has protective effects on several mechanisms of muscle loss, improving protein synthesis ${ }^{(85)}$.

It is also important to monitor and assess micronutrient levels and supplement accordingly. Overall, low levels or intakes of micronutrients such as vitamins A, E, D, B 6 and $\mathrm{B}_{12}$, $\mathrm{Zn}$ and Se have been associated with adverse clinical outcomes during viral infections ${ }^{(25,82)}$. For the assessment of micronutrients in COVID-19 patients, vitamins $\mathrm{A}$ and $\mathrm{D}$, vitamin $\mathrm{B}$, vitamin $\mathrm{C}$, $n$-3 PUFA, as well as Se, $\mathrm{Zn}$ and Fe should also be considered $^{(32,41) \text {. }}$

For cachectic patients, no guidelines exist for its prevention or treatment. Appetite stimulants, such as megestrol acetate and glucocorticoids, have been shown to increase appetite and weight ${ }^{(75)}$. However, in the acute phase of the COVID-19 disease and in the presence of intubation, these drugs are considered futile. Nowadays, clinicians should consider personalised nutritional treatment as target to prevent and treat cachexia for each patient. These interventions would include, as possible according to the general state of a patient, nutritional counselling, assessing and treating symptoms that have an impact on energetic intake, and a rational combination of pharmacological approaches directed at underlying pathophysiology ${ }^{(87)}$. Laboratory measurements of nutritional status, such as albumin levels, may be useful in certain cases. Table 3 summarises the purpose of nutritional recommendations for COVID-19 patients with cachexia during critical illness and/or admitted in a critical care unit.

The risk of refeeding syndrome in critically ill patients with COVID-19 should be monitored, as cachexia increases nutritional deficits ${ }^{(46)}$. In addition, electrolyte disturbances increase the risk of refeeding syndrome and contribute to arrhythmias and hemodynamic instability. So far, we are not aware of specific recommendations for patients after extubation and in the state of rehabilitation, but it is important to pay attention to the risk of dysphagia and swallowing assessment procedures should be applied to assess the possibility of implementing textureadapted food in this condition ${ }^{(82)}$.

\section{Conclusions}

Governments of countries around the globe should be dealing with the possibility of prolonged hospitalisation of COVID-19 patients and its enormous strains on the healthcare system. The deterioration of nutritional status, and consequently cachexia, increases the risk of mortality and needs to be treated with attention as other complications. Ensuring adequate nutrition in patients with COVID-19 who presented cachexia or associated symptoms has proven to be challenging due to intestinal alterations and inflammatory profile which complicate nutritional management. There is, however, little hard evidence of nutritional health approaches in assisting COVID-19 treatment or its management including cachexia. Nevertheless, COVID-19 is still a recently discovered disease, measures regarding maintenance of nutritional status and prevention of cachexia in hospitalised patients should be better explored for effective nutritional interventions in the future.

\section{Acknowledgements}

There are no sources of support.

This research received no external funding.

The authors' contributions were as follows: I. P. A. V. and N. M. S. contributed to data curation, analysing the data, interpretation of the findings, writing the original draft, review and editing. S. C. V. C. L. contributed to the review and editing and writing the original draft. A. P. T. F. contributed in the conceptualisation, data curation, methodology, project administration, writing the original draft, and review and editing.

The authors declare no conflict of interest. 


\section{References}

1. Zhu N, Zhang D, Wang W, et al. (2020) A novel coronavirus from patients with pneumonia in China, 2019. N Engl J Med 382, 727-733.

2. Chen N, Zhou M, Dong X, et al. (2020) Epidemiological and clinical characteristics of 99 cases of 2019 novel coronavirus pneumonia in Wuhan, China: a descriptive study. Lancet 395, 507-513

3. Lai C, Shih T, Ko W, et al. (2020) Severe acute respiratory syndrome coronavirus 2 (SARS-CoV-2) and coronavirus disease-2019 (COVID-19): the epidemic and the challenges. Int J Antimicrob Agents 55, 105924.

4. Guo G, Ye L, Pan K, et al. (2020) New insights of emerging SARS-CoV-2: epidemiology, etiology, clinical features, clinical treatment, and prevention. Front Cell Dev Biol 8, 410.

5. World Health Organization (2020) Coronavirus disease (COVID-19): weekly epidemiological update, 7 September 2020. World Health Organization. https://apps.who.int/iris/ handle/10665/334188.

6. Puig-Domingo M, Marazuela M \& Giustina A (2020) COVID-19 and endocrine diseases. A statement from the European Society of Endocrinology. Endocrine 68, 2-5.

7. Lippi G (2020) Chronic obstructive pulmonary disease is associated with severe coronavirus disease 2019 (COVID-19). Respir Med 167, 105941

8. Zhang J, Wu J, Sun X, et al. (2020) Associations of hypertension with the severity and fatality of SARS-CoV-2 infection: a metaanalysis. Epidemiol Infect 148, e106.

9. Alqahtani JS, Oyelade T, Aldhahir AM, et al. (2020) Prevalence, severity and mortality associated with COPD and smoking in patients with COVID-19: a rapid systematic review and meta-analysis. PLOS ONE 15, e0233147.

10. Hu Y, Sun J, Dai Z, et al. (2020) Prevalence and severity of corona virus disease 2019 (COVID-19): a systematic review and meta-analysis. J Clin Virol 127, 104371.

11. Li B, Yang J, Zhao F, et al. (2020) Prevalence and impact of cardiovascular metabolic diseases on COVID-19 in China. Clin Res Cardiol 109, 531-538.

12. Li X, Xu S, Yu M, et al. (2020) Risk factors for severity and mortality in adult COVID-19 inpatients in Wuhan. J Allergy Clin Immunol 146, 110-118.

13. Dietz W \& Santos-Burgoa C (2020) Obesity and its implications for COVID-19 mortality. Obesity 28, 1005-1005.

14. Zabetakis I, Lordan R, Norton C, et al. (2020) Covid-19: the inflammation link and the role of nutrition in potential mitigation. Nutrients $\mathbf{1 2}, 1466$.

15. Simonnet A, Chetboun M, Poissy J, et al. (2020) High prevalence of obesity in severe acute respiratory syndrome coronavirus-2 (SARS-CoV-2) requiring invasive mechanical ventilation. Obesity 28, 1195-1199.

16. Kalligeros M, Shehadeh F, Mylona EK, et al. (2020) Association of obesity with disease severity among patients with coronavirus disease 2019. Obesity 28, 1200-1204.

17. Borrego Utiel FJ, Segura Torres P, Pérez del Barrio MP, et al. (2010) La pérdida de peso en pacientes en hemodiálisis tras su hospitalización tiene relación con la duración de la estancia y con el grado de inflamación (Weight loss in haemodialysis patients after hospitalisation is related to the length of stay and the degree of inflammation). Nefrologia 30, 557-566.

18. Valla FV, Baudin F, Gaillard Le Roux B, et al. (2019) Nutritional status deterioration occurs frequently during children's ICU stay. Pediatr Crit Care Med 20, 714-721.

19. van Vliet IMY, Gomes-Neto AW, de Jong MFC, et al. (2020) High prevalence of malnutrition both on hospital admission and predischarge. Nutrition $\mathbf{7 7}, 110814$.
20. Li T, Zhang Y, Gong C, et al. (2020) Prevalence of malnutrition and analysis of related factors in elderly patients with COVID19 in Wuhan, China. Eur J Clin Nutr 74, 871-875.

21. Muscaritoli M, Anker SD, Argilés J, et al. (2010) Consensus definition of sarcopenia, cachexia and pre-cachexia: joint document elaborated by Special Interest Groups (SIG) "cachexia-anorexia in chronic wasting diseases" and "nutrition in geriatrics". Clin Nutr 29, 154-159.

22. Baethge C, Goldbeck-Wood S \& Mertens S (2019) SANRA-a scale for the quality assessment of narrative review articles. Res Integr Peer Rev 4, 2-8.

23. National Health Commission \& National Administration of Traditional Chinese Medicine (2020) Diagnosis and treatment protocol for novel coronavirus pneumonia (Trial Version 7). Chin Med J (Engl) 133, 1087-1095.

24. Jin Y, Yang H, Ji W, et al. (2020) Virology, epidemiology, pathogenesis, and control of COVID-19. Viruses 12, 372.

25. Romano L, Bilotta F, Dauri M, et al. (2020) Short report - medical nutrition therapy for critically ill patients with COVID-19. Eur Rev Med Pharmacol Sci 24, 4035-4039.

26. Stachowska E, Folwarski M, Jamioł-Milc D, et al. (2020) Nutritional support in coronavirus 2019 disease. Medicina (Kaunas) 56, 289

27. Guan W, Ni Z, Hu Y, et al. (2020) Clinical characteristics of coronavirus disease 2019 in China. $N$ Engl J Med 382, $1708-1720$

28. Jin X, Lian J-S, Hu J-H, et al. (2020) Epidemiological, clinical and virological characteristics of 74 cases of coronavirus-infected disease 2019 (COVID-19) with gastrointestinal symptoms. Gut 69, 1002-1009.

29. Zhang L \& Liu Y (2020) Potential interventions for novel coronavirus in China: a systematic review. J Med Virol 92, 479-490.

30. Jia H (2016) Pulmonary angiotensin-converting enzyme 2 (ACE2) and inflammatory lung disease. Shock 46, 239-248.

31. Briguglio M, Pregliasco FE, Lombardi G, et al. (2020) The malnutritional status of the host as a virulence factor for new coronavirus SARS-CoV-2. Front Med (Lausanne) 7, 146

32. Mendes RML, Pinho CPS, Santana NM, et al. (2019) Sarcopenia en pacientes coronarios hospitalizados (Sarcopenia in hospitalised coronary patients). Rev Chil Nutr 46, 11-17.

33. Huang C, Wang Y, Li X, et al. (2020) Clinical features of patients infected with 2019 novel coronavirus in Wuhan, China. Lancet 395, 497-506.

34. Wan S, Xiang Y, Fang W, et al. (2020) Clinical features and treatment of COVID-19 patients in northeast Chongqing. J Med Virol 92, 797-806.

35. Brill SE, Jarvis HC, Ozcan E, et al. (2020) COVID-19: a retrospective cohort study with focus on the over-80s and hospital-onset disease. BMC Med 18, 194.

36. Liu K, Fang YY, Deng Y, et al. (2020) Clinical characteristics of novel coronavirus cases in tertiary hospitals in Hubei Province. Chin Med J (Engl) 133, 1025-1031.

37. Xiong Y, Sun D, Liu Y, et al. (2020) Clinical and high-resolution CT features of the COVID-19 infection. Invest Radiol 55, 332-339.

38. Li K, Wu J, Wu F, et al. (2020) The clinical and chest CT features associated with severe and critical COVID-19 pneumonia. Invest Radiol 55, 327-331.

39. Cai Q, Chen F, Wang T, et al. (2020) Obesity and COVID-19 severity in a designated hospital in Shenzhen, China. Diabetes Care 2019, dc200576.

40. Klang E, Kassim G, Soffer S, et al. (2020) Severe obesity as an independent risk factor for COVID-19 mortality in hospitalized patients younger than 50 . Obesity 28, 1595-1599.

41. Hajifathalian K, Kumar S, Newberry C, et al. (2020) Obesity is associated with worse outcomes in COVID-19: analysis of early data from New York City. Obesity 28, 1606-1612. 
42. Laviano A, Koverech A \& Zanetti M (2020) Nutrition support in the time of SARS-CoV-2 (COVID-19). Nutrition 74, 110834.

43. Iddir M, Brito A, Dingeo G, et al. (2020) Strengthening the immune system and reducing inflammation and oxidative stress through diet and nutrition: considerations during the COVID-19 crisis. Nutrients 12, 1562.

44. Barker L, Gout B \& Crowe T (2011) Hospital malnutrition: prevalence, identification and impact on patients and the healthcare system. Int J Environ Res Public Health 8, 514-527.

45. White JV, Guenter P, Jensen G, et al. (2012) Consensus statement: Academy of Nutrition and Dietetics and American Society for Parenteral and Enteral Nutrition: characteristics recommended for the identification and documentation of adult malnutrition (undernutrition). J Parenter Enter Nutr 36, 275-283.

46. Arkin N, Krishnan K, Chang MG, et al. (2020) Nutrition in critically ill patients with COVID-19: challenges and special considerations. Clin Nutr 39, 2327-2328.

47. Baracos VE, Martin L, Korc M, et al. (2018) Cancer-associated cachexia. Nat Rev Dis Prim 4, 17105.

48. Evans WJ, Morley JE, Argilés J, et al. (2008) Cachexia: a new definition. Clin Nutr 27, 793-799.

49. Gualtieri P, Falcone C, Romano L, et al. (2020) Body composition findings by computed tomography in SARS-CoV-2 patients: increased risk of muscle wasting in obesity. Int J Mol Sci 21, 4670.

50. Yang Y, Ding L, Zou X, et al. (2020) Visceral adiposity and high intramuscular fat deposition independently predict critical illness in patients with SARS-CoV-2. Obesity 28, 2040-2048.

51. Petersen A, Bressem K, Albrecht J, et al. (2020) The role of visceral adiposity in the severity of COVID-19: highlights from a unicenter cross-sectional pilot study in Germany. Metabolism 110, 154317.

52. Baracos VE, Mazurak VC \& Bhullar AS (2019) Cancer cachexia is defined by an ongoing loss of skeletal muscle mass. Ann Palliat Med 8, 3-12.

53. Mourtzakis M, Prado CMM, Lieffers JR, et al. (2008) A practical and precise approach to quantification of body composition in cancer patients using computed tomography images acquired during routine care. Appl Physiol Nutr Metab 33, 997-1006.

54. Derstine BA, Holcombe SA, Goulson RL, et al. (2017) Quantifying sarcopenia reference values using lumbar and thoracic muscle areas in a healthy population. J Nutr Heal Aging 21, 180-185.

55. Li LQ, Huang T, Wang YQ, et al. (2020) COVID-19 patients clinical characteristics, discharge rate, and fatality rate of meta-analysis. J Med Virol $92,577-583$.

56. Jason LA, Evans M, Brown M, et al. (2010) What is fatigue? Pathological and nonpathological fatigue. $P M R \mathbf{2}, 327-331$.

57. Childs CE, Calder PC \& Miles EA (2019) Diet and immune function. Nutrients 11, 1933.

58. Shang Y, Xu C, Jiang F, et al. (2020) Clinical characteristics and changes of chest CT features in 307 patients with common COVID-19 pneumonia infected SARS-CoV-2: a multicenter study in Jiangsu, China. Int I Infect Dis 96, 157-162.

59. Zhang G, Hu C, Luo L, et al. (2020) Clinical features and shortterm outcomes of 221 patients with COVID-19 in Wuhan, China. J Clin Virol 127, 104364.

60. Zhu J, Ji P, Pang J, et al. (2020) Clinical characteristics of 3,062 COVID-19 patients: a meta-analysis. JMed Virol 92, 1902-1914.

61. Tian Y, Rong L, Nian W, et al. (2020) Review article: gastrointestinal features in COVID-19 and the possibility of faecal transmission. Aliment Pharmacol Ther 51, 843-851.

62. Saper CB, Romanovsky AA \& Scammell TE (2012) Neural circuitry engaged by prostaglandins during the sickness syndrome. Nat Neurosci 15, 1088-1095.
63. Aziz M, Fatima R, Lee-Smith W, et al. (2020) The association of low serum albumin level with severe COVID-19: a systematic review and meta-analysis. Crit Care 24, 255.

64. Luo P, Liu Y, Qiu L, et al. (2020) Tocilizumab treatment in COVID-19: a single center experience. J Med Virol 92, $814-818$.

65. Liu F, Li L, Xu M, et al. (2020) Prognostic value of interleukin-6, C-reactive protein, and procalcitonin in patients with COVID-19. J Clin Virol 127, 104370.

66. Picchianti Diamanti A, Rosado MM, Pioli C, et al. (2020) Cytokine release syndrome in COVID-19 patients, a new scenario for an old concern: the fragile balance between infections and autoimmunity. Int J Mol Sci 21, 3330.

67. Pepys MB \& Hirschfield GM (2003) C-reactive protein: a critical update. J Clin Invest 111, 1805-1812.

68. Sotoudeh E \& Sotoudeh H (2020) A hypothesis about the role of fetal hemoglobin in COVID-19. Med Hypotheses 144, 109994.

69. Alnor A, Sandberg MB, Gils C, et al. (2020) Laboratory tests and outcome for patients with COVID-19: a systematic review and meta-analysis. J Appl Lab Med 5, 1038-1049.

70. Liu X, Zhou H, Zhou Y, et al. (2020) Risk factors associated with disease severity and length of hospital stay in COVID-19 patients. J Infect 81, e95-e97.

71. Suleyman G, Fadel RA, Malette KM, et al. (2020) Clinical characteristics and morbidity associated with coronavirus disease 2019 in a series of patients in metropolitan Detroit. JAMA Netw Open 3, e2012270.

72. Lovesley D, Parasuraman R \& Ramamurthy A (2019) Combating hospital malnutrition: dietitian-led quality improvement initiative. Clin Nutr ESPEN 30, 19-25.

73. Arthur S, Noone J, Van Doren BA, et al. (2014) One-year prevalence, comorbidities and cost of cachexia-related inpatient admissions in the USA. Drugs Context 3, 212265.

74. Fukuta A, Saito T, Murata S, et al. (2019) Impact of preoperative cachexia on postoperative length of stay in elderly patients with gastrointestinal cancer. Nutrition 58, 65-68.

75. De Waele E, Mattens S, Honoré P, et al. (2015) Nutrition therapy in cachectic cancer patients. The Tight Caloric Control (TiCaCo) pilot trial. Appetite 91, 298-301.

76. Associação Brasileira de Cuidados Paliativos (2011) Consenso Brasileiro de Caquexia/anorexia (Brazilian Consensus on Cachexia/Anorexia). Rev Bras Cuid Paliativos 3, 23.

77. Christensen HM, Kistorp C, Schou M, et al. (2013) Prevalence of cachexia in chronic heart failure and characteristics of body composition and metabolic status. Endocrine 43, 626-634.

78. Okoshi MP, Capalbo RV, Romeiro FG, et al. (2017) Cardiac cachexia: perspectives for prevention and treatment. Arq Bras Cardiol 108, 74-80.

79. Argilés JM, Anguera A \& Stemmler B (2013) A new look at an old drug for the treatment of cancer cachexia: megestrol acetate. Clin Nutr 32, 319-324.

80. Ebner N, Steinbeck L, Doehner W, et al. (2014) Highlights from the 7th Cachexia Conference: muscle wasting pathophysiological detection and novel treatment strategies. J Cachexia Sarcopenia Muscle 5, 27-34.

81. Argilés JM, Busquets S, López-Soriano FJ, et al. (2012) Are there any benefits of exercise training in cancer cachexia? J Cachexia Sarcopenia Muscle 3, 73-76.

82. Barazzoni R, Bischoff SC, Breda J, et al. (2020) ESPEN expert statements and practical guidance for nutritional management of individuals with SARS-CoV-2 infection. Clin Nutr 39, 1631-1638.

83. Singer P, Blaser AR, Berger MM, et al. (2019) ESPEN guideline on clinical nutrition in the intensive care unit. Clin Nutr 38, 48-79. 
84. Morley JE, Argiles JM, Evans WJ, et al. (2015) Nutritional recommendations for the management of sarcopenia. J Am Med Dir Assoc 11, 391-396.

85. Esfahani M, Sahafi S, Derakhshandeh A, et al. (2018) The anti-wasting effects of L-carnitine supplementation on cancer: experimental data and clinical studies. Asia Pac J Clin Nutr 27, 503-511.
86. Holeček M (2017) Beta-hydroxy-beta-methylbutyrate supplementation and skeletal muscle in healthy and musclewasting conditions. I Cachexia Sarcopenia Muscle 8, 529-541.

87. Fearon K, Strasser F, Anker SD, et al. (2011) Definition and classification of cancer cachexia: an international consensus. Lancet Oncol 12, 489-495. 